\title{
RANCANG BANGUN MESIN PENGIRIS TALAS SEMIR
}

\author{
Wahyu K. Sugandi, Asep Yusuf, Ahmad Thoriq \\ Jurusan Teknik Pertanian dan Biosistem, FTIP, Universitas Padjadjaran \\ Jl. Raya Bandung Sumedang KM 21, Jatinangor 40600 \\ E-mail: sugandiwahyu@gmail.com
}

\begin{abstract}
Talas semir is superior commodity in Sumedang. Talas semir can be made into various type of snacks such as chips. The best quality of Talas semir chips can be produced by using the best cutting machine. Based on some experiment results of the cutting machine for producing talas semir chips, the design of cutting machine was not ergonomic. The machine was uncomfortable to be operated. This study aims to designing and creating the ergonomic cutting machine for producing talas semir chips. This machine consists of cutter, operator seat, product holder, axis of cutter disk, electric motor and transmission systems including belt and pulley. Based on the experiment, the theoretical and actual machine capacity are $47 \mathrm{~kg} / \mathrm{jam}$ and $38 \mathrm{~kg} / \mathrm{jam}$, respectively. Whereas, the efficiency of this machine is $81 \%$. By using this machine, the best quality of talas semir chips is produced aproximately $80 \%$ and 530 watt power is required.
\end{abstract}

Keywords: talas semir, Sumedang, cutting machine, talas semir chips

\section{PENDAHULUAN}

Talas merupakan tanaman pangan, yang dapat dijumpai hampir di seluruh Indonesia. Pemanenan umbi talas dilakukan setelah tanaman berumur $7-9$ bulan yang ditandai dengan mengeringnya daun. Umbi talas merupakan bahan pangan yang memiliki nilai gizi yang cukup baik. Komponen makronutrien dan mikronutrien yang terkandung di dalam umbi talas meliputi protein, karbohidrat, lemak, serat kasar, fosfor, kalsium, besi, tiamin, riboflavin, niasin, dan vitamin C. Komposisi kimia tersebut bervariasi tergantung pada beberapa faktor, seperti jenis varietas, usia, dan tingkat kematangan dari umbi. Faktor iklim dan kesuburan tanah juga turut berperan terhadap perbedaan komposisi kimia dari umbi talas. Nilai lebih dari umbi talas adalah kemudahan patinya untuk dicerna. Hal ini disebabkan oleh ukuran granula patinya yang cukup kecil dan patinya mengandung amilosa dalam jumlah yang cukup banyak (20-25\%). Selain itu, talas juga bebas dari gluten, maka pangan olahan dari talas dapat digunakan untuk diet individu yang memiliki alergi terhadap gluten [1].
Salah satu potensi besar dan variatif di Kabupaten Sumedang yang didukung oleh kondisi agroekosistem yang cocok untuk pengembangan komoditas pertanian dalam arti luas adalah talas semir [2]. Umbi talas Semir berasal dari Sumedang memiliki kulit umbi berwarna kecoklatan dengan warna daging umbi putih dan memiliki umbi dengan bentuk halter. Umbi talas Semir memiliki ukuran umbi dengan panjang $8-12 \mathrm{~cm}$. Talas semir memiliki rendemen umbi kupas terhadap berat umbi sebesar $75,43 \%$. Rendemen tersebut paling besar dibandingkan rendemen dari jenis talas lainnya seperti talas hijau (Bogor) sebesar $73,01 \%$, talas beneng (Pandeglang) 73,29\% dan talas mentega (Sukabumi) $59,41 \%$ [2]. Umbi talas dapat dimanfaatkan menjadi beberapa makanan untuk meningkatkan nilai ekonomi produk salah satunya adalah keripik talas. Untuk menghasilkan keripik talas yang berkualitas dengan hasil yang seragam membutuhkan mesin pengiris. Pengirisan secara manual memiliki kapasitas $78 \mathrm{~kg} / \mathrm{jam}$ sedangakan menggunakan mesin pemotong umbi talas dengan mekanisme engkol luncur pada putaran motor silinder pisau 213 rpm 
adalah $183 \mathrm{~kg} / \mathrm{jam}$ [3]. Mesin pengiris umbi tipe horizontal yang digerakkkan dengan motor listrik 0,5 HP pada putaran piringan pisau $473 \mathrm{rpm}$ menghasilkan irisan dengan ketebalan $1 \mathrm{~mm}$ sebanyak $147 \mathrm{~kg} / \mathrm{jam}$. Umbi - umbian yang dapat dipotong memiliki diameter maksimal $75 \mathrm{~mm}$ akan menghasilkan irisan dengan kualitas baik sebanyak $66,97 \%$ [4]. Beberapa penelitian tersebut belum memperhatikan aspek kenyamanan dari operator sehingga penelitian ini bertujuan melakukan rancang bangun mesin pengiris talas yang ergonomi.

\section{METODOLOGI PENELITIAN}

Penelitian ini dilaksanakan pada bulan April 2016 sampai dengan November 2016. Penelitian ini bertempat di Laboratorium Alat dan Mesin Pertanian Fakultas Teknologi Industri Pertanian, Universitas Padjadjaran, Jatinangor. Penelitian ini menggunakan peralatan dan kelengkapan laboratorium serta bengkel, antara lain sebagai berikut:
a. Mesin bubut
b. Mesin potong dan lipat logam
c. Multimeter
d. Clamp on meter
e. Tachometer, dll.

Sedangkan bahan dan komponen yang digunakan antara lain adalah:
a. Besi plat
b. Besi siku
c. Motor listrik
d. Mata pisau baja
e. Kabel listrik, dll

Penelitian ini menggunakan metode rekayasa (engineering) yaitu melakukan suatu kegiatan perancangan (design) yang tidak rutin sehingga terdapat suatu kontribusi yang baru baik dalam proses maupun bentuk.

\section{Kriteria Rancangan}

a) Kapasitas alat pengiris yang direncanakan adalah $50 \mathrm{~kg} / \mathrm{jam}$.

b) Mekanisme pengirisan menggunakan sistem pemotongan dengan pisau pengiris yang berputar secara radial.

c) Jumlah pisau pengiris sebanyak 3 buah yang melekat pada piringan pengiris. d) Mesin pengiris menggunakan penggerak mula motor listrik 1 PK sehingga menghasilkan irisan talas sesuai kebutuhan konsumen.

e) Alat yang dirancang mudah di bongkar pasang untuk kepentingan perawatan alat.

\section{Rancangan Fungsional}

Fungsi utama dari alat pengiris talas adalah untuk mengiris talas hingga pipih sesuai ukuran yang diinginkan. Untuk memenuhi fungsi utama maka diperlukan fungsi penunjang yaitu Hoper dan piringan pisau pengiris. Pada fungsi pendorong dan pengarah talas diperlukan hoper pemasukkan dan pada proses pengirisan talas diperlukan piringan dan pisau pengirs sehingga talas dapat teriris sesuai ukuran yang diharapkan.

\section{Rancangan Strukutural}

Hasil desain alat pengiris talas dengan motor listrik dibagi menjadi 4 bagian yaitu Rancangan Rangka Alat dan Dudukan Kursi Seperti pada Gambar 1. Rancangan rangka dudukan motor listrik dan piringan pengiris. Setelah rancangan ketiga unit alat tersebut selesai maka kemudian digabung menjadi satu kesatuan alat dengan harapan dapat menghasilkan irisan talas sesuai ukuran yang diinginkan.

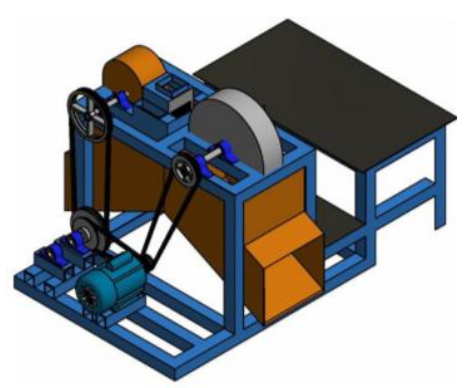

Gambar 1 Rangka dan dudukan kursi

\section{Rancangan Unit Tranmisi dan Pisau Pengiris}

Unit Trasmisi dan unit pengiris talas merupakan 2 bagian yang sangat penting untuk proses pengirisan. 

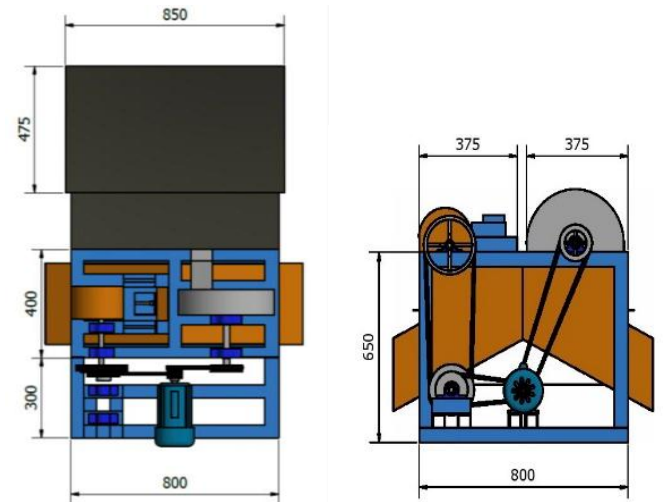

Gambar 2 Unit Transmisi dan Pisau Pengiris

Adapun bahan baku terbuat dari besi dan khusu untuk pisau pengiris terbuat dari stainless steel adapun posisi operator tepat didepan piringan pengiris seperti yang disajikan pada Gambar 2.

\section{Analisis Teknik Pengiris Talas}

Analisis teknik yang dilakukan terhadap mesin pengiris talas meliputi: analisis kebutuhan daya penggerak, transmisi daya, pin, analisis bantalan (bearing), kekuatan rangka, dan kekuatan las. Analisis teknik bertujuan untuk mengetahui kekuatan bahan dari setiap komponen mesin yang dilakukan dengan cara perhitungan secara teoritis dan pengamatan langsung yang terjadi di lapangan.

a) Kebutuhan Daya Penggerak

Daya penggerak diperlukan untuk menggerakkan mekanisme kerja pengiris talas. Perhitungan daya penggerak dapat menggunakan Persamaan 1 [5]

$P=\frac{2 \pi \times M_{t} \times N}{60}$

$$
\begin{array}{ll}
\mathrm{P} & =\text { Daya yang dibutuhkan (watt) } \\
\mathrm{N} & =\text { Jumlah putaran puli (RPM) } \\
\mathrm{M}_{\mathrm{t}} & =\text { Momen puntir (Nm) }
\end{array}
$$

\section{b) Analisis Poros}

Analsis yang dilakukan pada poros yaitu mengenai ukuran (diameter) poros serta kekuatan poros dalam menyalurkan daya. Poros menerima beban puntir dan beban lentur, karena poros ini dapat berfungsi untuk meneruskan daya Untuk analisis tersebut dilakukan perhitungan meliputi diameter poros dan kecepatan kritis poros.

Daya rencana dapat dihitung dengan menggunakan Persamaan 2 [5].

$$
P_{d}=f_{c} \times \mathrm{P}
$$

Dimana :

$P_{d} \quad=$ Daya yang direncanakan $(\mathrm{kW})$

$f_{c}=$ Faktor koreksi daya

$\mathrm{P} \quad=$ Daya nominal output motor penggerak $(\mathrm{kW})$

Faktor-faktor Koreksi Daya yang Akan Ditransmisikan, $f_{c}[5]$.

\begin{tabular}{lc}
\hline $\begin{array}{l}\text { Daya yang akan } \\
\text { ditransmisikan }\end{array}$ & $f_{c}$ \\
\hline $\begin{array}{l}\text { Daya rata-rata yang } \\
\text { diperlukan }\end{array}$ & $1,2-2,0$ \\
$\begin{array}{l}\text { Daya maksimum } \\
\text { yang diperlukan }\end{array}$ & $0,8-1,2$ \\
Daya normal & $1,0-1,5$ \\
\hline
\end{tabular}

(Sularso dan Suga, 1997)

Momen puntir (momen rencana) dapat dihitung menggunakan Persamaan 3 [5].

$$
\mathrm{T}=9,74 \times 10^{5} \frac{\mathrm{P}_{\mathrm{d}}}{\mathrm{n}_{1}}
$$

Deformasi yang disebabkan oleh momen puntir pada poros harus dibatasi, untuk poros yang dipasang pada mesin umum dalam kondisi kerja normal, besarnya defleksi puntiran dibatasi sampai 0,25-0,3 derajat [5]. Besarnya defleksi puntiran dapat dihitung dengan menggunakan Persamaan 4 [5].

$$
\theta=584 \frac{\mathrm{Tl}}{\mathrm{G} \mathrm{d}^{4}}
$$

Dimana :

$\begin{aligned} \theta & =\text { Defleksi puntiran }\left({ }^{0}\right) \\ \mathrm{d} & =\text { Diameter poros }(\mathrm{mm}) \\ \mathrm{I} & =\text { Panjang poros }(\mathrm{mm}) \\ \mathrm{T} & =\text { Momen Puntir }(\mathrm{kg} \cdot \mathrm{mm}) \\ \mathrm{G} & =\text { Modulus geser }\left(8,3 \times 10^{3}\right)\left(\mathrm{kg} / \mathrm{mm}^{2}\right)\end{aligned}$ 
Poros merupakan salah satu komponen penting dalam mentransmisikan daya berupa putaran, dimana besarnya diameter suatu poros mempengaruhi besarnya putaran. Besarnya diameter poros dapat dihitung dengan Persamaan 5 [5].

$\mathrm{d}_{s}^{3}=\frac{16}{\pi x S S} \sqrt{\left(K_{b} x M_{b}\right)^{2}+\left(K_{t} x M_{t}\right)^{2}}$

Dimana :

$\mathrm{d}_{\mathrm{s}}=$ Diameter poros $(\mathrm{mm})$

$\mathrm{K}_{\mathrm{b}}=$ Faktor koreksi momen lentur, Nilai $\mathrm{K}_{\mathrm{b}}$ adalah 1,5 untuk poros dengan momen lentur tetap; 1,5-2,0 untuk beban lenturan ringan, dan 2,0-3,0 untuk beban tumbukan berat

$\mathrm{M}_{\mathrm{b}}=$ Momen lentur maksimal $(\mathrm{Nm})$

$\mathrm{K}_{\mathrm{t}} \quad=$ Faktor koreksi momen puntir, Nilai $\mathrm{K}_{\mathrm{t}}$ adalah 1,0 untuk beban dikenakan secara halus, 1,0-1,5 jika terjadi sedikit lendutan dan tumbukan, 1,53,0 jika terjadi kejutan atau tumbukan besar

$\mathrm{M}_{\mathrm{t}}=$ Momen Torsi (Nm)

Ss $=$ Tegangan geser $40 \times 10^{6} \mathrm{MPa}$

Nilai momen torsi yang bekerja dalam perhitungan diameter poros. Dihitung dengan menggunakan Persamaan 6 [5].

$$
M t=\frac{P}{\omega}
$$

Dimana:

$\mathrm{M}_{\mathrm{t}}=$ Momen torsi $(\mathrm{Nm})$

$\mathrm{P}=$ Daya dari Motor listrik (Watt)

$\omega=$ RPM rol pengupas $(\mathrm{rad} / \mathrm{s})$

Putaran kritis poros adalah putaran tertinggi yang dapat ditahan oleh poros. Putaran kritis poros yang dimiliki sebuah benda yang berputar dapat dihitung dengan menggunakan Persamaan 7 [5].

$$
\omega c=\sqrt{\frac{g \cdot \sum \omega \delta}{\sum \omega \delta^{2}}}
$$

Dimana:

$\omega c=$ Putaran Kritis Poros

Demi keamanan maka putaran kerja poros maksimum tidak boleh melebihi $80 \%$ dari putaran kritisnya [5].

\section{c) Analisis Pin dan Spi}

Pin pada mesin berfungsi sebagai komponen yang dapat menetapkan bagianbagian mesin agar tidak terjadi slip atau pergeseran. Biasanya pin digunakan untuk mengikat puli atau roda gigi pada poros. Momen torsi dapat dihitung dengan menggunakan Persamaan 8 [5].

$$
M t=\frac{P}{\omega}
$$

Dimana:

$M t=$ Momen Torsi $(\mathrm{Nm})$

$\mathrm{P}=$ Daya (watt)

$\omega=$ Kecepatan putar (RPM)

Gaya tangensial yang bekerja pada pin yang terletak pada komponen elemen - elemen mesin dapat dihitung dengan menggunakan Persamaan 9 [5].

$$
F=\frac{M t}{r}
$$

Dimana :

$$
\begin{aligned}
\mathrm{F} & =\text { Gaya tangensial }(\mathrm{N}) \\
\mathrm{T} & =\text { Momen torsi }(\mathrm{Nm}) \\
\mathrm{r} & =\text { Jari-jari poros }(\mathrm{m})
\end{aligned}
$$

Untuk menghitung besarnya diameter dari pin yang digunakan pada bagian-bagian mesin agar tidak bergeser diperoleh dari nilai tekanan yang diizinkan, menggunakan Persamaan 10 [5].

$$
\mathrm{P}_{\mathrm{s}}=\frac{F}{A}=\frac{F}{1 / 4 \pi D^{2}}
$$

Dimana :

Ps = Tekanan yang diizinkan $\left(\mathrm{N} / \mathrm{m}^{2}\right)$

$\mathrm{F}=$ Gaya tangensial $(\mathrm{N})$ 


$$
\text { D = Diameter pin (m) }
$$

Pada alat. Spi ini digunakan untuk mencegah terjadinya slip pada putaran roda gigi. Untuk menghitung ukuran dari spi yang digunakan udian menggunakan Persamaan 11 [5].

$$
F=\tau_{a} A
$$

Dengan :

$$
\begin{aligned}
\mathrm{A}= & \text { Luas spi, } \mathrm{b} \times \mathrm{t}\left(\mathrm{m}^{2}\right) \\
\mathrm{F}= & \text { Gaya }(\mathrm{N}) \\
\tau_{a}= & \text { Normal / Allowable shear stress, } 25 \\
& \text { Mpa }
\end{aligned}
$$

d) Analisis Bantalan

Bantalan merupakan elemen mesin yang dapat menumpu poros berbeban, sehingga putaran atau gerakan bolak baliknya dapat berlangsung secara halus, aman, dan panjang waktu pakainya. Bantalan harus cukup kokoh untuk memungkinkan poros serta elemen mesin lainnya bekerja dengan baik. Jika bantalan tidak berfungsi dengan baik maka prestasi seluruh sistem akan menurun atau tak dapat bekerja dengan semestinya [5].

Beban yang ditopang oleh poros ketika proses pengupasan berlangsung merupakan gabungan dari beberapa berat antara lain beban puli, roda gigi dan tegangan tali. Nilai beban tersebut dapat dihitung dengan menggunakan Persamaan 12 [5].

$$
F_{r}=w_{1}+w_{2}+w_{3+}+w_{4}
$$

Beban tersebut merupakan beban radial yang bisa dihitung dengan menggunakan Persamaan 13 [5].

$$
\operatorname{Pr}=f w \times F r
$$

Dimana :

$\operatorname{Pr}=$ Beban radial yang ditumpu

$\mathrm{Fw}=$ Faktor beban, nilainya sebesar 1,1-1,3 untuk kerja biasa

$\mathrm{Fr}=$ Beban radial yang dibawa poros
Faktor kecepatan untuk bantalan bola dapat dihitung dengan menggunakan Persamaan 14 [5].

$$
f_{n}=\left(\frac{33,3}{n}\right)^{1 / 3}
$$

Dimana :

$f_{n} \quad=$ Faktor kecepatan

$\mathrm{n}=$ Putaran poros

Sedangkan perhitungan faktor umur untuk bantalan dapat dihitung dengan Persamaan 15 [5].

$$
F_{h}=f_{n} \frac{C}{P_{r}}
$$

Dimana :

$f_{h}=$ Faktor umur

C = Beban nominal dinamis spesifik $(\mathrm{kg})$

$\operatorname{Pr}=$ Beban ekuivalen dinamis $(\mathrm{kg})$

Umur nominal untuk bantalan dapat dihitung dengan menggunakan Persamaan 16.

$\operatorname{Lh}=500 . f_{h}{ }^{3}$

e) Analisis Kekuatan Rangka

Rangka berfungsi sebagai penahan beban yang berada di atasnya dimana rangka tersebut akan mengalami defleksi dan lengkungan sebagai akibat dari beban yang ditopangnya. Analisis rangka dihitung berdasarkan lendutan dan beban kritis yang diizinkan. Beban yang dapat ditopang oleh baris menggunakan persamaan 17 [6].

$$
\delta \quad=\frac{P L^{3}}{48 E I}
$$

Dimana:

$\delta=$ Lendutan yang diizinkan $(\mathrm{mm})$

$P=$ Beban yang bekerja pada rangka $(\mathrm{kg})$

$L=$ Panjang kolom baris $(\mathrm{mm})$

$E=$ Modulus elastisitas rangka $\left(\mathrm{kg} / \mathrm{mm}^{2}\right)$

$I=$ Momen inersia rangka $\left(\mathrm{mm}^{4}\right)$ 
Kemudian lendutan yang terjadi akibat dari beban yang ditopang oleh rangka dibandingkan dengan lendutan izin yang dapat dihitung menggunakan Persamaan 18.

$$
\delta_{\text {izin }}=\frac{1}{300} L_{1}
$$

\section{e) Analisis Kekuatan Las}

Pengelasan adalah metode pengikat logam dengan leburan. Terdapat dua tipe utama las yaitu las temu dan las sudut. Kekuatan las ini dapat menopang beban rangka jika kekuatan las temu lebih besar dari gaya yang bekerja pada rangka [6] seperti pada Persamaan 19.

$$
F \leq t \times t \times I
$$

Dimana :

$$
\begin{aligned}
& F=\text { Gaya yang bekerja pada rangka }(\mathrm{N}) \\
& T=\text { Tegangan izin }\left(\mathrm{N} / \mathrm{m}^{2}\right) \\
& t=\text { Tebal bidang las }(\mathrm{m}) \\
& I=\text { Panjang bidang las }(\mathrm{m}) .
\end{aligned}
$$

\section{HASIL DAN PEMBAHASAN}

\section{Mesin Pengiris Talas Semir Hasil Rancangan}

Mesin pengiris talas hasil rancangan terdiri atas beberapa bagian diantaranya pisau pengiris, kursi operator, luaran hasil irisan, poros piringan pisau pengiris,motor listrik, transmisi belt dan pulley seperti dapat dilihat pada Gambar 3.

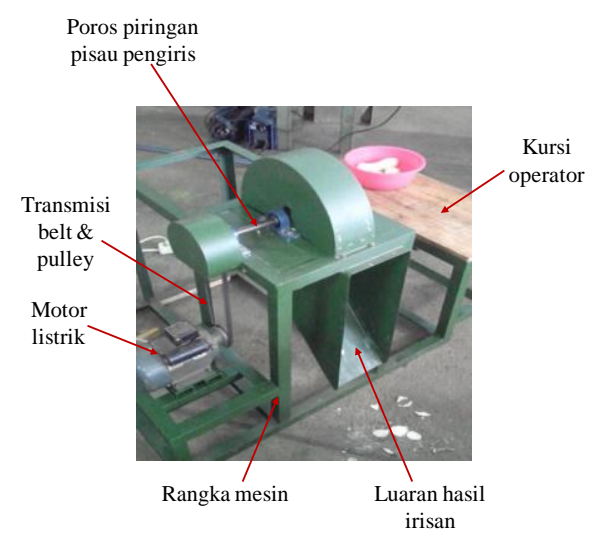

Gambar 3 Mesin Pengiris Talas Semir

\section{Uji Kinerja Mesin Pengiris Talas Indeks Performansi}

Indeks performansi mesin pengiris talas ialah perbandingan antara jumlah hasil irisan talas yang utuh (tidak rusak) dengan total keseluruhan. Adapun jumlah total hasil irisan talas sebanyak 150 irisan talas, dengan jumlah irisan talas yang patah atau tidak sesuai ukuran sebanyak 30 irisan dan jumlah yang utuh sebanyak 120 irisan. Sehingga indeks performansi mesin pengiris talas dapat dihitung dengan menggunakan Persamaan 20.

$$
\begin{aligned}
& P I=\frac{P u}{P t} \times 100 \% \\
& P I=\frac{120}{150} \times 100 \% \\
& P I=80 \%
\end{aligned}
$$

Nilai indeks performansi mesin pengirs talas yang mencapai $80 \%$ menunjukkan bahwa hasil pengirisan talas mesin tersebut sudah cukup baik.

\section{Kapasitas Pengirisan}

Kapasitas mesin pengiris talas menunjukkan banyaknya jumlah irisan talas yang dihasilkan oleh pengiris talasa per satuan waktu tertentu. Kapasitas pengirisan talas terbagi menjadi dua yaitu kapasitas teoritis pengirisan dan kapasitas aktual pengirisan. Perbedaan antara kapasitas teoritis pengirisan dengan kapasitas aktual pengirisan terletak pada waktu yang digunakan untuk satu kali pengirisan.

Kapasitas teoritis (Kt) merupakan banyaknya talas yang dihasilkan dalam setiap pengirisan dibagi dengan waktu ratarata pada setiap pengirisan, tanpa memperhitungkan waktu yang digunakan untuk persiapan bahan dan persiapan alat. Sedangkan kapasitas aktual (Ka) adalah banyaknya talas yang dihasilkan dalam setiap pengirisan dibagi dengan waktu total yang digunakan untuk setiap pengirisan talas.

Waktu yang dibutuhkan untuk mengiris talas dapat dilihat pada Tabel 1. Sedangkan 
data perhitungan waktu pengirisan. Berdasarkan data hasil pengukuran waktu pencetakan, diketahui bahwa kapasitas teoritis pengiris talas adalah 47 Tabel 1. Waktu Pengirisan Talas

\begin{tabular}{cccccc}
\hline $\begin{array}{c}\text { Kebutuhan } \\
\text { Waktu }\end{array}$ & Ulangan I & Ulangan II & Ulangan III & $\begin{array}{c}\text { Rata - } \\
\text { rata }\end{array}$ & $\begin{array}{c}\text { Kapasitas } \\
\text { Pengirisan }\end{array}$ \\
\hline Teoritis & 77 detik & 80 detik & 74 detik & 77 detik & $47 \mathrm{~kg} / \mathrm{jam}$ \\
Aktual & 90 detik & 100 detik & 97 detik & 95 detik & $38 \mathrm{~kg} / \mathrm{jam}$ \\
\hline
\end{tabular}

Massa: 1000 gram

\section{Efisiensi Pengirisan}

Efisiensi pengirisan adalah perbandingan antara kapasitas aktual pengirisan dengan kapasitas teoritis pengirisan. Berdasarkan hasil perhitungan kapasitas aktual dan kapasitas teoritis pengirisan, maka nilai efisiensi mesin pengiris talas dapat dihitung dengan Persamaan 21.

$\eta=\frac{K a}{K t} \times 100 \%$

$\eta=\frac{38}{47} x 100 \%$

$\eta=81 \%$

Berdasarkan hasil perhitungan diatas, nilai efisiensi pengirisan mencapai $81 \%$. Hal tersebut menunjukkan bahwa efisiensi pengirisan sudah cukup baik. Adapun salah satu faktor yang mempengaruhi kualitas pengirisan tersebut adalah posisi sudut potong irisan talas antara pisau dengan piringan pisau.

\section{Kebutuhan Daya}

Kebutuhan daya pengirisan dihitung berdasarkan beban yang terjadi pada mesin pengiris Talas. Hasil perhitungan diperoleh bahwa daya yang dibutuhkan untuk mengiris talas adalah 530 Watt. $\mathrm{kg} / \mathrm{jam}$ dan kapasitas aktual pencetakan adalah $38 \mathrm{~kg} / \mathrm{jam}$.

\section{KESIMPULAN}

1. Dimensi Mesin Pengiris Talas Panjang $1475 \mathrm{~mm}$, Tinggi $750 \mathrm{~mm}$ dan Lebar $800 \mathrm{~mm}$

2. Kapasitas teoritis mesin pengiri talas adalah $38 \mathrm{~kg} / \mathrm{jam}$.

3. Kapasitas aktual mesin pengiris talas adalah $47 \mathrm{~kg} / \mathrm{jam}$.

4. Efesiensi pengirisan adalah $81 \%$.

5. Daya yang dibutuhkan untuk mengiris talas adalah 540 watt.

\section{DAFTAR PUSTAKA}

[1] Koswara, Sutrisno. 2013. Teknologi Pengolahan Umbi-Umbian Bagian 1: Pengolahan Umbi Talas. Bogor: Southeast Asian Food And Agricultural Science And Technology (SEAFAST)

[2] Bapppeda Sumedang. 2005. RPJPD Kabupaten Sumedang 2005 - 2025. Badan Perencanaan Daerah Kabupaten Sumedang.

[3] Apriani Rd.R.N, Setyadjit. Aprah, M. 2011. Karakteristik Empat Jenis Umbi Talas Varian Mentega, Hijau, Semir, dan Beneng Serta Tepung Yang Dihasilkan Dari Keempat Varian Umbi Talas. Jurnal IImiah Dan Penelitian, No.1 Vol.1 Retrieved from https://jurnaldanmajalah.wordpress.com/ 2011/01/04/6/

[4] Gasni D. 2007. Karakteristik mesin pemotong ubi talas dengan mekanisme engkol peluncur. Jurnal TeknikA 2(27) : $62-68$ 
[5] Sholeh M., Pratama G.H., Pratama H.Y., dan Apair R.Y. 2012. Rancang Bangun Prototype Pengiris Umbi. Koswara, S. 2013. Pengolahan Umbi Talas. Southeast Asian Food and Agricultural Science and Technology (SEAFAST) Centre Research and Community Service Institution, Bogor Agricultural university.
[6] Sularso dan Kiyokasu, Suga. 1997. Dasar Perencanaan dan Perancangan Elemen Mesin. Cetakan Kesembilan.Pradnya Paramita. Jakarta.

[7] Singer, F. L., Andrew, P. and Darwin, S. 1995. Kekuatan Bahan (Teori kokoh_strenght of Material). Edisi Ketiga. Erlangga. Jakarta. 